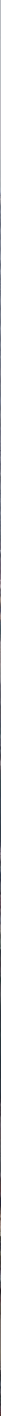

\title{
INFLUENCING TAX POLICY REFORM IN VIETNAM THE CASE OF DECREE 20
}




\section{BACKGROUND: THE HIGH PRICE OF TAX AVOIDANCE IN VIETNAM}

Taxes have always been the most important source of revenue in Vietnam, accounting for $80-90 \%$ of the total state budget. ${ }^{1}$ In 2013, the government revealed that a shocking 720 out of 870 foreign enterprises operating in Vietnam had avoided taxes. ${ }^{2}$ In 2016, the government began to revise tax regulations with a particular focus on the practice of transfer pricing, ${ }^{3}$ which can be manipulated to play a major role in corporate tax avoidance.

This tax policy reform is vital for raising domestic revenues. It is estimated that developing countries, including Vietnam, are losing \$100bn per year due to tax avoidance by MNCs through the manipulation of transfer pricing and other profit-shifting practices. This amount is more than enough to pay for an education for the 124 million children currently out of school worldwide, and for health interventions that could save the lives of six million children globally. In a country like Vietnam, which has a large budget deficit, lost tax revenues could be used to fund public education and healthcare -sectors which are currently subsidized up to $40 \%$ by out-of-pocket payments ${ }^{4}$ from ordinary Vietnamese citizens.

\section{WHAT OXFAM IS CALLING FOR}

Transparency is vital to restore trust in tax systems. Governments and CSOs in developing countries need more information about what taxes MNCs pay and where, so that tax avoidance and evasion can be better detected and addressed - and better rules agreed and enforced. This would lead to fairer tax systems, enabling developing countries to collect more tax that would pay for essential services and reduce poverty and inequality.

A major challenge that countries like Vietnam face in the international tax system is their limited access to key financial data - including data on tax paid by MNCs on profits made in their country - as the exchange of this information is largely between rich-country tax authorities. This makes it very difficult for developing countries to detect, much less address, cases of tax evasion or avoidance.

Since 2015, Oxfam in Vietnam has been lobbying for changes in tax policy. Specifically, Oxfam have been calling for public country-by-country reporting - requiring MNCs to publish key financial data, including the profits their subsidiaries make and the taxes they pay in the country of operation instead of only reporting consolidated accounts in their home country.

Oxfam is also calling on other countries to introduce public country-by-country reporting to benefit countries like Vietnam. If, for example, the EU introduced public country-bycountry reporting, it could help ensure that MNCs labove a certain size) operating in the EU would be obliged to file their country-by-country reports online. This would allow Vietnamese tax authorities to access information about the tax affairs of MNCs with a presence in the EU and also operating in Vietnam, to identify the risk of tax avoidance.

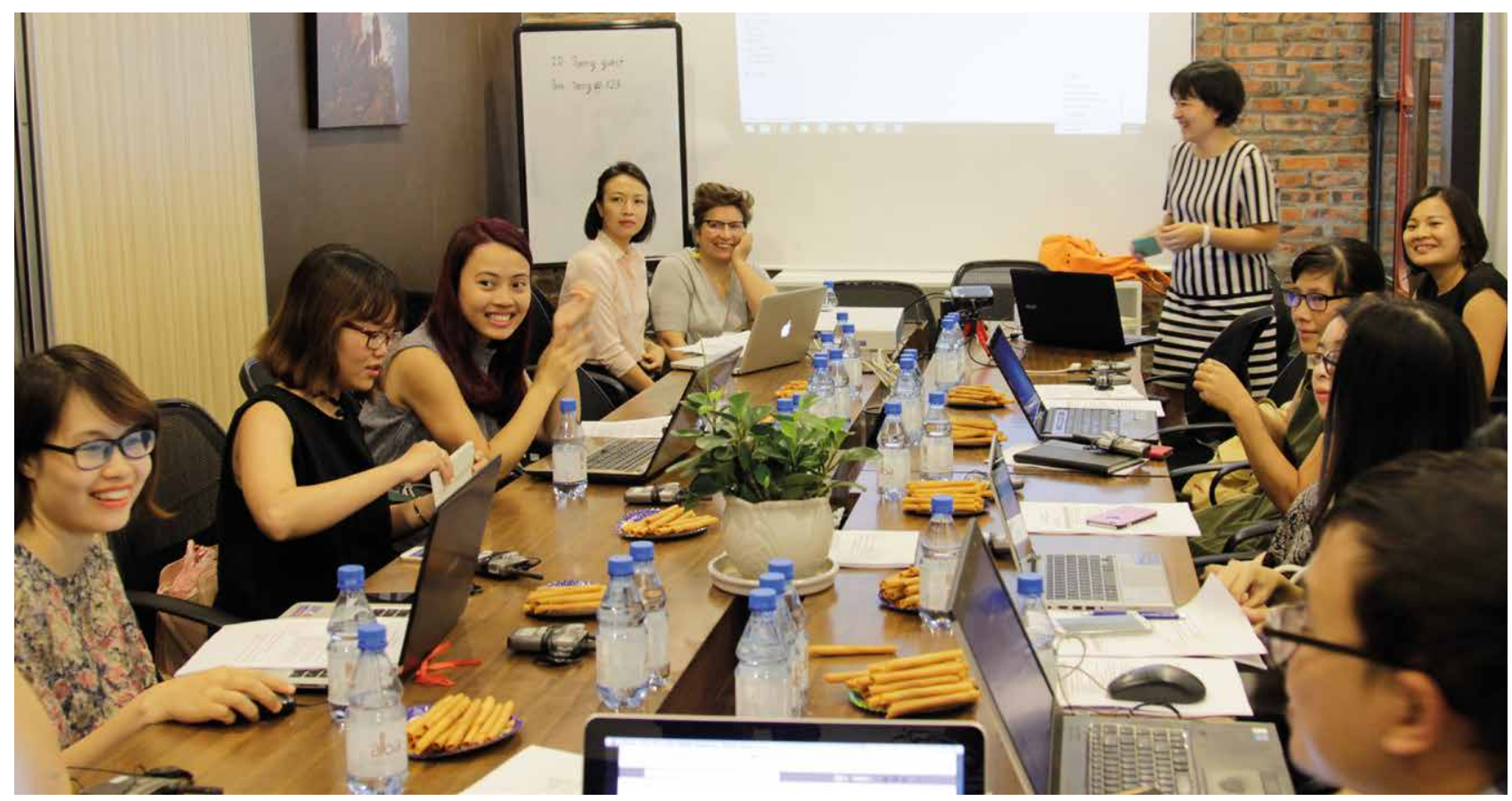




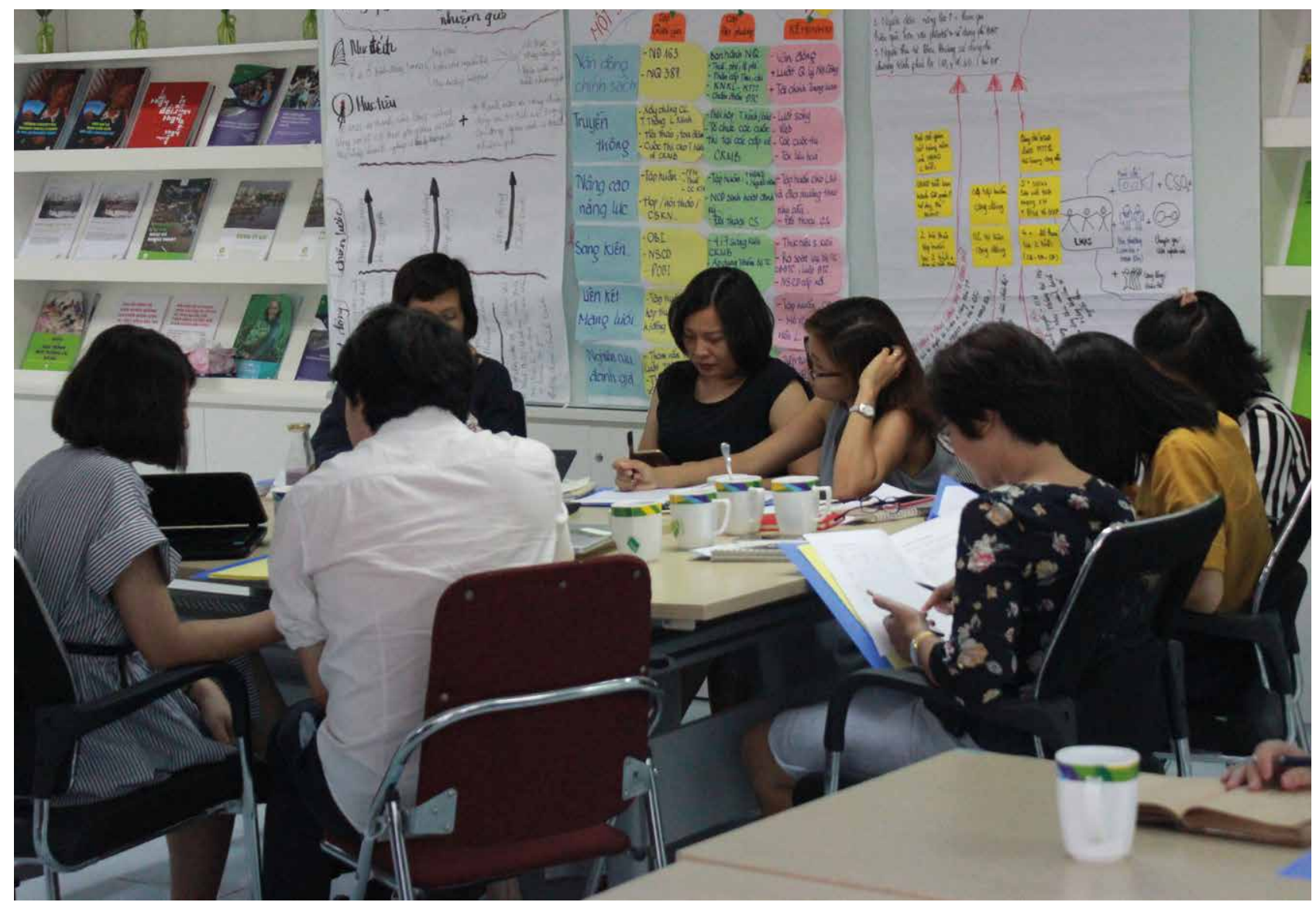

Public country-by-country reporting would help the Vietnamese government to improve tax rules to prevent avoidance in the first place. It would also enable CSOs, journalists and researchers in Vietnam to hold companies to account to ensure they pay their fair share of tax.

\section{BUILDING AN ALLIANCE FOR CHANGE IN VIETNAM}

Oxfam in Vietnam has been working with a broad-based coalition of CSOs and others to help push for greater transparency of MNCs tax affairs through country-by-country reporting - leading to the formation of Vietnam's first-ever Tax Justice Alliance. ${ }^{5}$

A visit by an Oxfam international tax policy specialist allowed the Alliance to engage with the government at an expert level, and this level of engagement convinced the Vietnam Initiative (VNI), a respected research institute, to partner with the Alliance in joint advocacy efforts.

Oxfam also began to collaborate with the Vietnam Chamber of Commerce and Industry (VCCI) which is a very useful ally for the Alliance as it represents the business interests of national and foreign companies in Vietnam. This partnership came about through a meeting with a VCCI representative who was involved in the first round of consultations on the tax reform known as 'Decree 20'.

The VCCI shares an interest with Oxfam in promoting tax transparency and business integrity. The VCCI supported the Alliance by sharing critical information with Oxfam about the ongoing negotiations on Decree 20. VCCl also helped the Alliance members to identify transparency as the common issue of interest among the competing stakeholders that include companies, auditing firms and the tax department. This focus on a common denominator in a complex policy environment helped steer Oxfam's advocacy efforts.

The Alliance sought to engage the General Department of Taxation (GDT) - the government department responsible for the process around Decree 20. Over a period of persistent engagement, the Department members came to appreciate Oxfam's and partners insightful contributions to the extent that they invited us to comment on the GDT's draft transferpricing documents and welcomed our international tax experts to a meeting for sharing views.

\section{ADVOCACY RESULTS}

Gaining recognition for the role of civil society in tax policy reform was a significant achievement in itself. And as a result of the Alliance's sustained engagement with the relevant authorities, the government agreed to introduce a regulation in Decree 20 which requires MNCs to file country-by-country reports directly with Vietnam's Tax Bureau. Although this information is only available to the tax bureau and not the general public, it is an important first step in ensuring that MNCs pay their fair share of tax and compensate for the public assets, infrastructure and services they use in Vietnam.

This local filing mechanism in Vietnam is a welcome initial response to the information gap on MNC profits and tax paid in-country, and provides an important example that other countries in the Global South can follow. Because of this regulation, Vietnam no longer has to rely on tax treaties or information-exchange agreements to gain information on foreign parent companies, making it easier for the government to identify and address tax avoidance or abuses of transfer pricing. 


\section{WHAT'S NEXT?}

Our work does not stop here. The current regulation on country-by-country reporting only targets a limited number of MNCs and, as mentioned above, does not require public reporting. We will therefore advocate for improvements to Decree 20 in line with future advances in EU regulation on public country-by-country reporting. Only when MNCs' country-by-country reports are public and accessible online, will CSOs be able to play the vital role of independent watchdog to help clamp down on corporate tax-dodging behaviour.

\section{SUCCESSFUL CHANGE STRATEGIES USED BY OXFAM IN VIETNAM}

- Convening expert meetings where we shared Oxfam's experience of supporting other countries on revising

transfer-pricing rules, especially on country-by-country reporting.

- Persistent networking with key government taxation officers and frequently updating them on our relevant work on tax justice.

- Sharing policy briefs that were of high quality and relevant to the national context.

- On request, we offered specific legal recommendations (i.e. article revisions) from diverse perspectives, with the help of our expert local partner organization, VNI.

- Opening up channels of dialogues to a broad range of actors and viewpoints. Collaboration with the Chamber of Commerce, a business interest organization, opened new doors and generated fresh ideas.

- Identifying a common focus - transparency - in a complicated policy area motivated diverse partners to work together and present a united front.

- Forming an alliance around a common interest enhanced our resources, reach, credibility, influence and legitimacy.

- Brokering partnerships between Oxfam, the Tax Justice Alliance members and government officials was delicate and time-consuming, but critical to ensuring confidence of all parties in the aims of our advocacy work.

- Taking advantage of the right timing for this push - Vietnam is suffering from a serious budget deficit and the government is looking for solutions to fill the financing gap.

- Alignment to global campaign methodology and research by applying Oxfam's global analysis on fiscal justice to the national context provided the needed evidence base for our advocacy.

- Linking national influencing with global campaigns by inviting Oxfam's global tax experts to share their knowledge with the team and the government authorities provided valuable expertise and technical support that strengthened our influencing efforts.

\section{References}

1 Oxfam's Tax Incentive Report 2017, p. 21

2 http://www.thanhniennews.com/business/vietnam-victim-of-corporatetax-evasion-25350.html; In one case, a world-famous soft drinks company began investing in Vietnam in 1994, and for 20 years declared losses while simultaneously expanding its business in the country. The company only paid its first corporate income taxes in 2014.

3 Transfer pricing happens whenever two companies that are part of the same multinational group trade with each other: when the parties establish a price for the transaction, this is the transfer price. Aggressive intragroup pricing especially for debt and intangibles - has played a major role in corporate tax avoidance, and it was one of the issues identified when the OECD released its base erosion and profit shifting (BEPS) action plan in 2013. The OECD's 2015 final BEPS report called for country-by-country reporting and stricter rules for transfers of risk and intangibles.

4 Health Financing Group/Ministry of Health (Vietnam General Health Accounts): $38.7 \%$ (2013).

\section{(C) Oxfam International August 2018}

The Mobilising Progressive Domestic Resources for Quality Public Services Project in Kenya and Vietnam was funded by the Ministry of Foreign Affairs of Finland between 2014 and 2018.

This publication is copyright but the text may be used free of charge for the purposes of advocacy, campaigning, education, and research, provided that the source is acknowledged in full. The copyright holder requests that all such use be registered with them for impact assessment purposes. For copying in any other circumstances, or for re-use in other publications, or for translation or adaptation, permission must be secured and a fee may be charged. Email policyandpractice@oxfam.org.uk

5 The Tax Justice Alliance member organizations are: Vietnam Initiative (VNI), Vietnam Institute for Economic and Policy Research (VEPR), Oxfam, Towards Transparency (local chapter of Transparency International), Center for Education Promotion and Empowerment of Women (CEPEW), Ech Phu Ho lyouth activist organization) and Budget Transparency Coalition (BTAP).

\section{Photos}

Front cover: Hanoi City, Vietnam. Photo: Eleanor Farmer/Oxfam

Page 2: Oxfam tax expert Susana Ruiz, Tax Justice Policy Lead, provided the team and media in Vietnam with a global perspective on national issues. Photo: Vu Ngoc Linh/Oxfam

Page 3; The Tax Justice Alliance came together to develop a joint influencing strategy having identified transparency as the key issue uniting the seven participating organisations. Photo: Vu Ngoc Linh/Oxfam

The information in this publication is correct at the time of going to press. Published by Oxfam GB for Oxfam International under ISBN 978-1-78748-316-3 in August 2018. D0I: 10.21201/2018.3163

Oxfam GB, Oxfam House, John Smith Drive, Cowley, Oxford, 0X4 2JY, UK.

\section{Oxfam}

Oxfam is an international confederation of 20 organizations networked together in more than 90 countries, as part of a global movement for change, to build a future free from the injustice of poverty. Please write to any of the agencies for further information, or visit www.oxfam.org 